\title{
Release of immunoreactive oxytocin and neurophysin I by cultured luteinizing bovine granulosa cells
}

\author{
V. Geenen', J. J. Legros' ${ }^{1}$, \\ M. T. Hazée-Hagelstein, F. Louis-Kohn ${ }^{1}$, M. J. Lecomte-Yerna, \\ A. Demoulin ${ }^{2}$ and P. Franchimont \\ Laboratoire de Radioimmunologie, Unité de Neuroendocrinologie 1 , \\ Centre Hospitalier Universitaire B23, Université de Liège - Sart Tilman, B 4000 Liège and \\ Département de Gynécologie et d'Obstétrique ${ }^{2}$, \\ Maternité de l'Hôpital de Bavière, Boulevard de la Constitution, B 4020 Liège, Belgique
}

\begin{abstract}
We investigated the production of oxytocin (OT) and oxytocin-neurophysin (bNp I) by bovine granulosa cells cultured in presence of $10 \%$ foetal calf serum, a condition known to induce spontaneous luteinization of these cells. The production of immunoreactive OT was significantly higher in the cultures of granulosa cells harvested from large follicles than in those derived from small follicles. Chromatography on Sephadex G-25 showed similar elution sites of ovarian and synthetic OT, while high performance liquid chromatography revealed two peaks of OT-immunoreactivity, one of which $( \pm 65 \%$ of the total immunoreactivity) coincided with synthetic OT. In another experiment, we could observe a gradual increase of OT, bNp I and progesterone production by granulosa cells derived from large follicles, in relation with the incubation time. The mean molar ratio OT: bNp I was $2.2 \pm 0.5$ (SEM), and we found a significant positive correlation between the production of $\mathrm{OT}$ and bNp I ( $=0.77 ; P<0.01)$ and between the production of $\mathrm{OT}$ and progesterone $(\mathrm{r}=0.80 ; P<0.01)$. Furthermore, the cellular $\mathrm{OT}$ and $\mathrm{bNp} I$ content of large follicles-derived granulosa cells before culture was 4-5 times lower than the total amount of OT and bNp I produced during a 72- $\mathrm{h}$ incubation, suggesting an active synthesis of these peptides.

These data show that bovine granulosa cells are able to produce $\mathrm{OT}$ and bNp I, probably by an active biosyn-
\end{abstract}

Requests for reprints:

Vincent Geenen, Unité de Neuroendocrinologie, Laboratoire de Radioimmunologie, Université de Liège - Sart Tilman, CHU-B23, B 4000 Liège, Belgique. thesis as observed in the hypothalamo-neurohypophysial system and that the granulosa productions of OT, bNp I and progesterone are closely related.

Oxytocin (OT) has been shown to be present in the corpus luteum of the sheep (Wathes \& Swann 1982), cow (Fields et al. 1983; Wathes et al. 1983) and human (Wathes et al. 1982; Khan-Dawood \& Dawood 1983). The identification of the specific OT carrier protein, bovine neurophysin I (bNp I), has also been reported in extracts of bovine corpus luteum (Wathes et al. 1983). The OT gene is highly expressed in the bovine corpus luteum during the mid-luteal phase of the oestrous cycle (Ivell \& Richter 1984) and studies using incorporation of $\left.{ }^{35} \mathrm{~S}\right]$ cysteine show that isolated ovine and bovine luteal cells can synthetise OT by way of precursor protein similar to that found in the hypothalamus (Swann et al. 1984).

The function of ovarian OT is still rather unclear; some observations suggest that OT could intervene in the luteolytic process either by exerting an inhibitory effect on the progesterone synthesis (Tan et al. 1982a,b) or by stimulating the release of the luteolytic prostaglandin $\mathrm{F}_{2 \alpha}\left(\mathrm{PGF}_{2 \alpha}\right)$ from the uterus (Roberts et al. 1976); $\mathrm{PGF}_{2 \alpha}$, in turn, induces the secretion of ovarian OT (Flint \& Sheldrick 1982), so that OT and $\mathrm{PGF}_{2 \alpha}$ would engage in a positive feedback loop leading to luteolysis. However, OT could play another role in 
the control of the oestrous cycle as, in cows and sheep, the highest values of circulating OT levels and amounts of ovarian extracts are found in the early and mid-luteal phases (Schams et al. 1982, 1983; Wathes et al. 1984), and as the peripheral OT levels increase in synchrony with changes in the progesterone production but start to decline again shortly before progesterone levels decrease at luteolysis (Schams et al. 1983).

We have judged of interest to study the secretion of the OT-related neurohypophysial peptides by cultured bovine granulosa cells undergoing luteinization and to investigate the relationship with the increase of the progesterone production observed in such conditions.

\section{Material and Methods}

\section{Cultures of bovine granulosa-cells}

The technique has been described in detail before (Henderson \& Moon 1979; Henderson \& Franchimont 1981). Bovine ovaries were obtained from a local slaughterhouse and carried to the laboratory in chilled minimum essential medium (modified) with Earle's salts (EMEM), supplemented with HEPES buffer $(20 \mathrm{~mm})$, glutamine $(2 \mathrm{mM})$, penicillin $(50 \mathrm{IU} / \mathrm{ml})$, streptomycin $(50 \mu \mathrm{g} / \mathrm{ml})$, amphotericin B $(0.625 \mu \mathrm{g} / \mathrm{ml})$ and non-essential amino acids. Ovarian follicles were dissected and the granulosa cells scraped with a platinum loop into chilled EMEM, supplemented as above. The pooled cells were washed three times with the medium and cell clumps were dissociated with gentle mechanical agitation and repeated aspiration with a glass pipette; an aliquot was taken to determine total cell number using a haemocytometer and the mean percentage of viable cells determined with nigrosin dye approached to $45 \% .10^{5}$ live cells' were cultured in multi-welled tissue culture dishes at $37^{\circ} \mathrm{C}$ in $1.0 \mathrm{ml}$ culture medium consisting of $10 \%(\mathrm{v} / \mathrm{v})$ foetal calf serum and 90\% EMEM supplemented as above, but without HEPES buffer. The gas-phase was $5 \%$ $\mathrm{CO}_{2}: 95 \%$ air. After a 24-h period necessary for adherence of viable cells, the medium was removed and replaced by fresh one.

In a first experiment, granulosa cells were harvested from large $(>10 \mathrm{~mm}$ in diameter) and small $(<10 \mathrm{~mm}$ in diameter) follicles, and cultured for $48 \mathrm{~h}$ after the medium replacement. After incubation, the medium was collected and stored at $-20^{\circ} \mathrm{C}$ before further analyses (hormone assays, chromatography on Sephadex G-25 and high performance liquid chromatography).

In a second experiment, we performed cultures of granulosa cells collected from large follicles only; after the medium replacement, the cultures (total number $=$
12) were divided in three groups of four replicate cultures and were incubated for 24,48 or $72 \mathrm{~h}$. The media were then collected and stored until assays of $\mathrm{OT}, \mathrm{bNp} I$ and progesterone. At the end of incubation, the cells were washed and stained with haematoxylin and eosin; the granulosa cells formed a monolayer and appeared healthy; morphological aspect of luteinization was indicated by cellular hyperplasia and hypertrophy with an increase in the cytoplasm:nucleus ratio. Five samples of $10^{5}$ viable non-incubated granulosa cells collected from large follicles were submitted to lysis in $1.0 \mathrm{ml}$ distilled water in order to determine the initial $\mathrm{OT}$ and $\mathrm{bNp} I$ cellular content.

\section{Radioimmunoassay of $O T$}

The antiserum was raised against OT coupled to thyroglobulin as described by Robinson (1980): $2 \mathrm{mg}$ synthetic OT (Sandoz, Basel, Switzerland - $462 \mathrm{IU} / \mathrm{mg}$ ) were conjugated to $5 \mathrm{mg}$ bovine thyroglobulin (Sigma, type 1) in $3.0 \mathrm{ml}$ water, using $7 \mathrm{mg} \mathrm{1-(3-dimethylaminopropyl)-}$ 3-ethylcarbodiimide (Aldrich, Europe). After $18 \mathrm{~h}$ at room temperature, $7 \mathrm{mg}$ hydroxylamine- $\mathrm{HCl}$ was added and the mixture was incubated for $5 \mathrm{~h}$ at room temperature. The antibody was produced in female rabbits by injection of $0.5 \mathrm{mg}$ OT-thyroglobulin mixture in $1.0 \mathrm{ml}$ water, emulsified in an equal volume of complete Freund's adjuvant. Rabbits were injected eight times monthly into multiple paravertebral intradermal sites and bleeding occurred monthly after the fifth immunization. The antisera were titrated in serial dilutions against radioiodinated $O T$ and the dilution binding $30-40 \%$ of the tracer was used in preparing the assay.

OT was labelled with ${ }^{125}$ I according to the chloramine $\mathrm{T}$ method (Greenwood et al. 1963) and purified on a DEAE-Sephadex A- 25 column $(0.8 \times 7 \mathrm{~cm})$ as previously described (Legros \& Franchimont 1971). Mean specific activity of radioiodinated $\mathrm{OT}$ ranged from 200 to 550 $\mathrm{mCi} / \mathrm{mg}$. The omission of the reduction step by metabisulfite did not improve the immunoreactivity nor the specific activity of the tracer. The radioimmunoassay procedure was carried out in $0.05 \mathrm{M}$ ammonium bicarbonate buffer, $\mathrm{pH} 7.5$, supplemented with ovalbumin $(4 \mathrm{~g} / \mathrm{l}), \mathrm{Na}_{2}$-EDTA $(7 \mathrm{~g} / \mathrm{l})$, tween $20(5 \mathrm{ml} / \mathrm{l})$ and trasylol $(50000 \mathrm{IU} / 1)$. The best antiserum $\left(\mathrm{AsO}_{2}\right.$, final dilution 1: 9000 ) was incubated for 4 days at $4^{\circ} \mathrm{C}$ with $0.1 \mathrm{ml}$ [125I]OT ( $\pm 6000 \mathrm{CPM})$ and $0.1 \mathrm{ml}$ various amounts of synthetic OT or samples to be assayed. Separation of bound and free antigen was performed by double antibody precipitation of bound OT. The standard curve for radioimmunoassay of OT is shown in Fig. 1. The lowest detectable value of $\mathrm{OT}$ was $5 \mathrm{pg} / \mathrm{tube}$ and the intercept of $50 \%$ relative binding on the curve corresponded to $140 \mathrm{pg}$ synthetic OT. There was an incomplete crossreaction with arginine-vasotocin (AVT), while cross-reactions for other peptides when compared to $O T$ at a $B / B_{o}$ displacement of $50 \%$ (on a weight basis) were: argininevasopressin (AVP), $0.3 \%$; bovine neurophysin I (bNp I), 


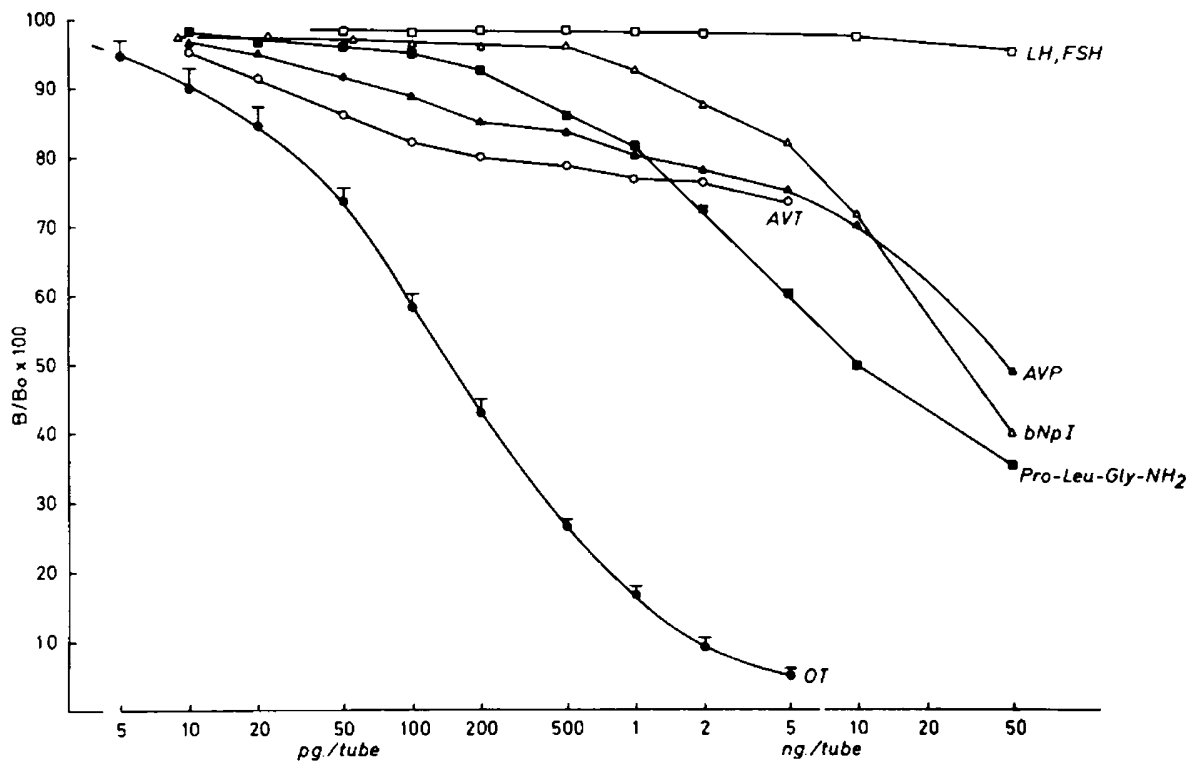

Fig. 1 .

Standard curve for the radioimmunoassay of oxytocin (OT) and cross-reaction curves with arginine-vasotocin (AVT), arginine-vasopressin (AVP), bovine oxytocin-neurophysin I (bNp I), terminal tripeptide of OT (Pro-Leu-Gly- $\mathrm{NH}_{2}$ ), bovine follicle stimulating hormone (FSH) and luteinizing hormone ( $\mathrm{LH})$.

$0.41 \%$; OT terminal tripeptide (Pro-Leu-Gly- $\mathrm{NH}_{2}$ ), $1.25 \%$; follicle stimulating hormone (FSH) and luteinizing hormone $(\mathrm{LH}),<0.003 \%$. Validation of the radioimmunoassay was assessed by the measurement of OT concentrations after addition of known amounts of synthetic OT into the culture medium (EMEM) containing $10 \%$ foetal calf serum or not; no significant interference could be observed and the OT content of non-incubated culture medium supplemented with $10 \%$ foetal calf serum was below the limit of detection. Therefore, a direct assay of OT in unextracted culture medium was allowed with a sensitivity of $5 \mathrm{pg} / \mathrm{tube}(50 \mathrm{pg} / \mathrm{ml}$ medium).

The intra-assay coefficient of variation ranged from 4.5 to $8.5 \%$ along the curve, and the inter-assay coefficient, assayed by replicate estimate of the same 5 medium samples within different radioimmunoassays, was $13.5 \%$.

\section{Radioimmunoassay of $b N p I$}

The antiserum against bNp I was raised in a rabbit and the cross-reaction with bovine vasopressin-neurophysin II (bNp II) was $<0.5 \%$ and other bovine anterior pituitary hormones $<0.1 \%$. The radioimmunoassay procedure has been described in detail elsewhere by Legros (1976).

\section{Radioimmunoassay of progesterone}

Antiserum $\mathrm{PO}_{4} / 11 \mathrm{Tg}$ was kindly supplied by Prof. Umberto Rosa (Consiglio delle Riserche, Pisa, Italy) and used at a final dilution of 1:5000; tracer was [1251]progesterone (IRE, Fleurus, Belgium), conjugated as 11-succinyl-tyrosine. The percentage cross-reaction of the antiserum in comparison of progesterone $(100 \%)$ was $0.3 \%$ for $17 \alpha$-hydroxyprogesterone, $0.05 \%$ for pregnenolone and $<0.001 \%$ for $20 \alpha$-hydroxy-4-pregnen-3-one, corticosterone, cortisol, $5 \alpha$-dihydrotestosterone, 4-androstene-3,17-dione, testosterone and oestradiol-17 $\beta$. The limit of the detection was $0.05 \mathrm{ng} / \mathrm{ml}$. Separation of bound and free hormones was performed with dextrancoated charcoal $(0.1 \%$ dextran T- $70,1 \%$ neutral charcoal in albumin phosphate buffer, $\mathrm{pH}$ 7.4); centrifugation was made after $15 \mathrm{~min}$ and radioactivity of the pellet (free hormone) was counted.

\section{Chromatography}

Five samples $(0.4 \mathrm{ml}$ each) of incubated media were pooled from cultures of large follicles-derived granulosa cells and were applied to the top of a column $(0.9 \times$ $27 \mathrm{~cm}$ ) of Sephadex G-25, equilibrated with $0.1 \mathrm{~N}$ formic

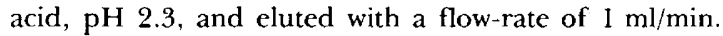
Fractions $(1.0 \mathrm{ml})$ were collected and lyophilized; later, they were redissolved in $0.2 \mathrm{ml}$ radioimmunoassay buffer and assayed for OT in duplicate. A similar chromatography was carried out twice in the same conditions and the material from the main peak of OT-immunoreactivity (fractions $13-18$ ) was pooled and lyophilized separately before high performance liquid chromatography (HPLC) analysis. 
The HPLC system consisted of a Waters Associates Model $6000 \mathrm{~A}$ solvent delivery system, equipped with a model 480 LC Spectrophotometer, a Model 720 system controller and a Model $330 \mathrm{UV} / \mathrm{vis}$ absorbance detector. The column was a Waters Associates $10 \mu \mathrm{m}$ Bondapak C- $18(0.4 \times 30 \mathrm{~cm})$. The eluent consisted of $1 \%$ trifluoroacetic acid and a linear gradient of 0 to $60 \%$ acetonitrile was used with a duration of $90 \mathrm{~min}$ at a flow-rate of $1 \mathrm{ml} / \mathrm{min}$. Fractions of $1.0 \mathrm{ml}$ were collected, lyophilized and assayed for OT in duplicate.

\section{Statistical analysis}

All values are given as mean $\pm \mathrm{SEM}$. When $\mathrm{OT}$ values were below the limit of detection, they were not taken into account, and their number was mentioned. The data from the first experiment were subjected to analysis by unpaired Student's $t$-test.

The coefficent of linear correlation was calculated by the method of the least squares.

\section{Results}

As indicated in Table 1, immunoreactive OT could be detected in the medium after a 48-h incubation of bovine granulosa cells harvested from large follicles, and was undetectable only in 2 out of 20 cultures. The OT and progesterone productions were significantly lower in the cultures of granulosa cells from small follicles, and OT-immunoreactivity was not detected in 12 out of 20 cultures.

\section{Table 1.}

Oxytocin (OT) and progesterone production by cultured bovine granulosa cells, obtained from large or small follicles.

\begin{tabular}{l|c|c}
\hline & \multicolumn{2}{|c}{ Origin of granulosa cells } \\
\cline { 2 - 3 } & $\begin{array}{c}\text { Large follicles } \\
(>10 \mathrm{~mm} \text { diam. })\end{array}$ & $\begin{array}{c}\text { Small follicles } \\
(<\mathrm{I} 0 \mathrm{~mm} \text { diam. })\end{array}$ \\
\hline $\begin{array}{c}\text { Oxytocin (OT) } \\
\left(\mathrm{pg} / 10^{5} \mathrm{cells} / 48 \mathrm{~h}\right)\end{array}$ & $83 \pm 4.5^{*}$ & $66.2 \pm 3.2$ \\
$\begin{array}{c}\text { Undetectable } \\
\text { Progesterone } \\
\left(\mathrm{ng} / 10^{5} \text { cells } / 48 \mathrm{~h}\right)\end{array}$ & $2 / 20$ & $12 / 20$ \\
Undetectable & $0 / 20$ & $72 \pm 4$ \\
\hline
\end{tabular}

Values are given as mean \pm SEM of detectable values.

${ }^{*} P<0.05(\mathrm{t}=1.85 ; \mathrm{df}=24), * * P<1 \times 10^{-9}(\mathrm{t}=8.26$; $\mathrm{df}=38$ ) compared to the corresponding values in the small follicles-derived cultures (unpaired Student's $t$-test).
Fig. 2 shows the Sephadex G-25 elution profile of OT-immunoreactivity contained in $2.0 \mathrm{ml}$ of pooled media collected from 5 cultures of large follicles-derived granulosa cells. The main peak appeared in the same position as standard OT; it was preceded by a smaller peak in fraction 12, and some OT-immunoreactivity was detected up to fraction 18. The amount of OT eluted corresponded to $\pm 95 \%$ of the total OT content measured in the pooled media.

HPLC analyses of the material contained in fractions 13-18 eluted from two separate Sephadex G-25 chromatographies are shown in Fig. 3. Two peaks of OT-immunoreactivity were eluted in each run; the second peak was co-eluted with standard OT and corresponded to $\pm 65 \%$ of the total OTimmunoreactivity eluted. An OT-like immunoreactivity ( $\pm 35 \%$ ) was detected in eluates collected at 19-20 min of the system, but it was not co-eluted with standard preparations of AVT or AVP.

As indicated in Fig. 4, we could observe a gradual increase of the granulosa cell production of OT, $\mathrm{bNp} I$ and progesterone in relation with the duration of the cultures. The mean molar ratio $\mathrm{OT}$ : bNp I was $2.2 \pm 0.5$; there was a significant positive relationship between the production of $\mathrm{OT}$ and bNp I $(r=0.77 ; P<0.01)$ and between the production of $\mathrm{OT}$ and progesterone $(\mathrm{r}=0.80$; $P<0.01)$. The initial cellular OT and bNp I content of large follicles-derived granulosa cells was $59 \pm 5.4 \mathrm{pg} / 10^{5}$ cells and $0.49 \pm 0.05 \mathrm{ng} / 10^{5}$ cells, respectively. This was $4-5$ times lower than the total amount of OT and bNp I produced during the 72-h incubation (respectively $295 \pm \mathrm{pg} / 10^{5}$ cells and $2.22 \pm 0.11 \mathrm{ng} / 10^{5}$ cells).

\section{Discussion}

When bovine granulosa cells are cultured in medium containing $10 \%$ foetal calf serum, they undergo morphological and functional modifications indicative of a spontaneous luteinization (Henderson \& Moon 1979). Our data demonstrate that, in the same conditions, luteinizing bovine granulosa cells release immunoreactive OT and bNp I in the culture medium. A significant difference appears between the productions of OT and progesterone by granulosa cells from large or small follicles, suggesting an influence of the stage of granulosa cell differentiation. Considering the 


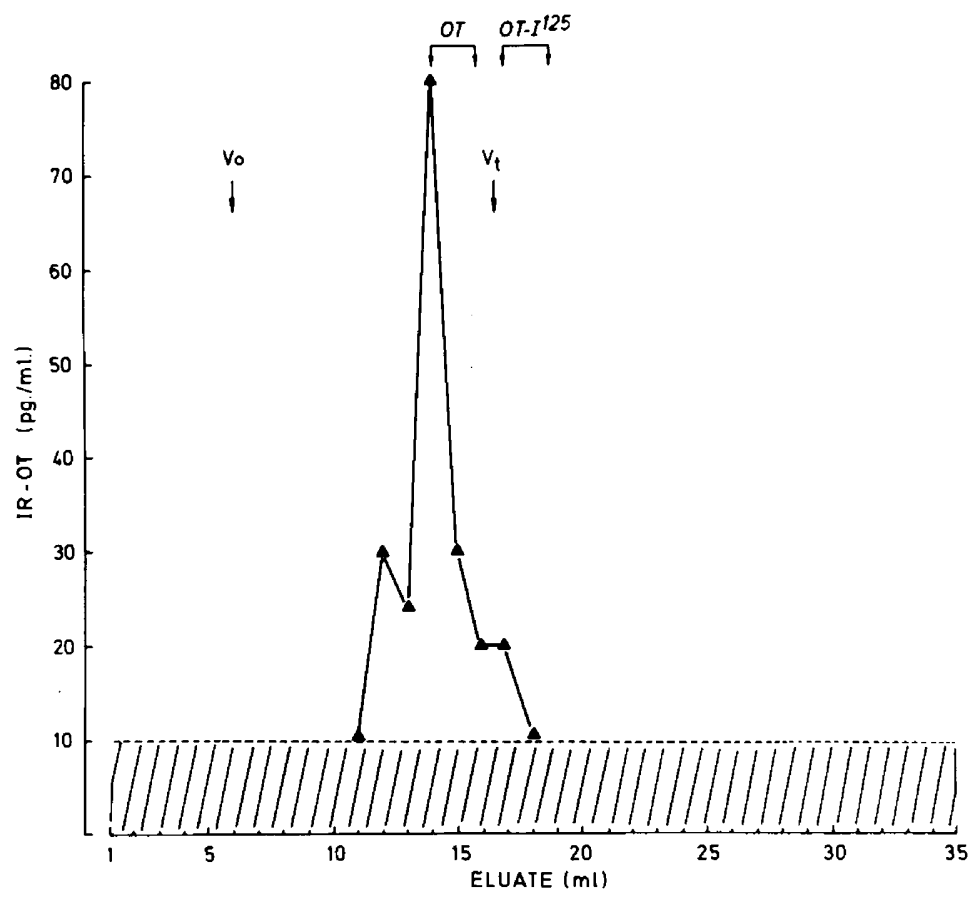

Fig. 2.

Sephadex G-25 column $(0.9 \times 27 \mathrm{~cm})$ chromatography of incubated media pooled from cultures of large follicles-derived granulosa cells. Maximal elution sites of synthetic and iodinated OT are represented. Each eluted fraction $(1.0 \mathrm{ml})$ was lyophilized, redissolved in $0.2 \mathrm{ml}$ buffer and assayed for OT in duplicate, so the limit of detection was brought to $10 \mathrm{pg} / \mathrm{ml}$.

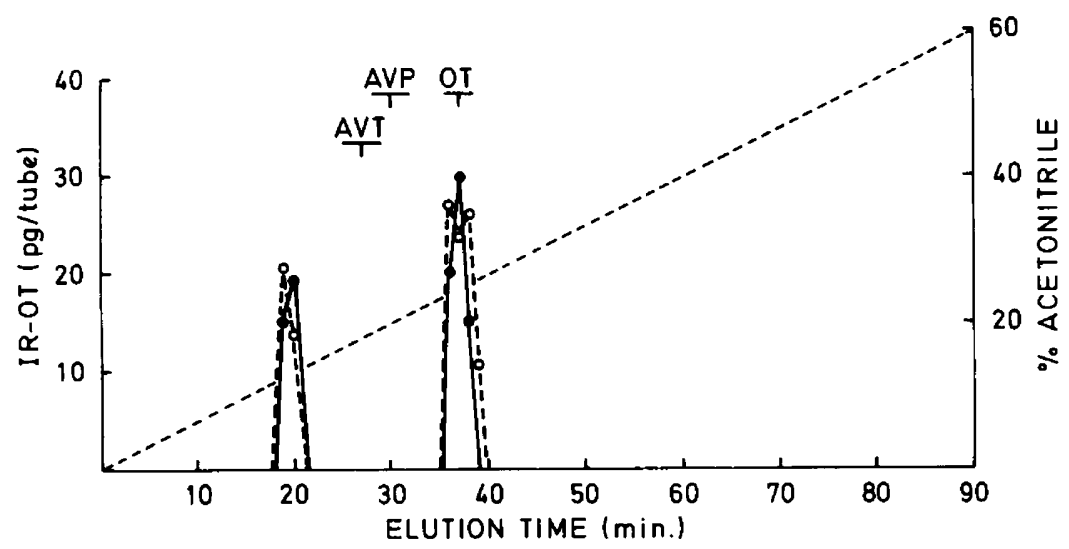

Fig. 3.

HPLC profiles of the OT-immunoreactivity contained in the main peak (fractions 13-18) eluted from two separate Sephadex G-25 chromatographies. Each eluted $(1.0 \mathrm{ml})$ fraction was lyophilized, redissolved in $0.2 \mathrm{ml}$ buffer and assayed for OT in duplicate, so the limit of detection was brought to $10 \mathrm{pg} / \mathrm{ml}$. The position of standard peptides OT (Sandoz, Switzerland), AVT and AVP (UCB - Bioproducts, Belgium) was determined using UV detector. 


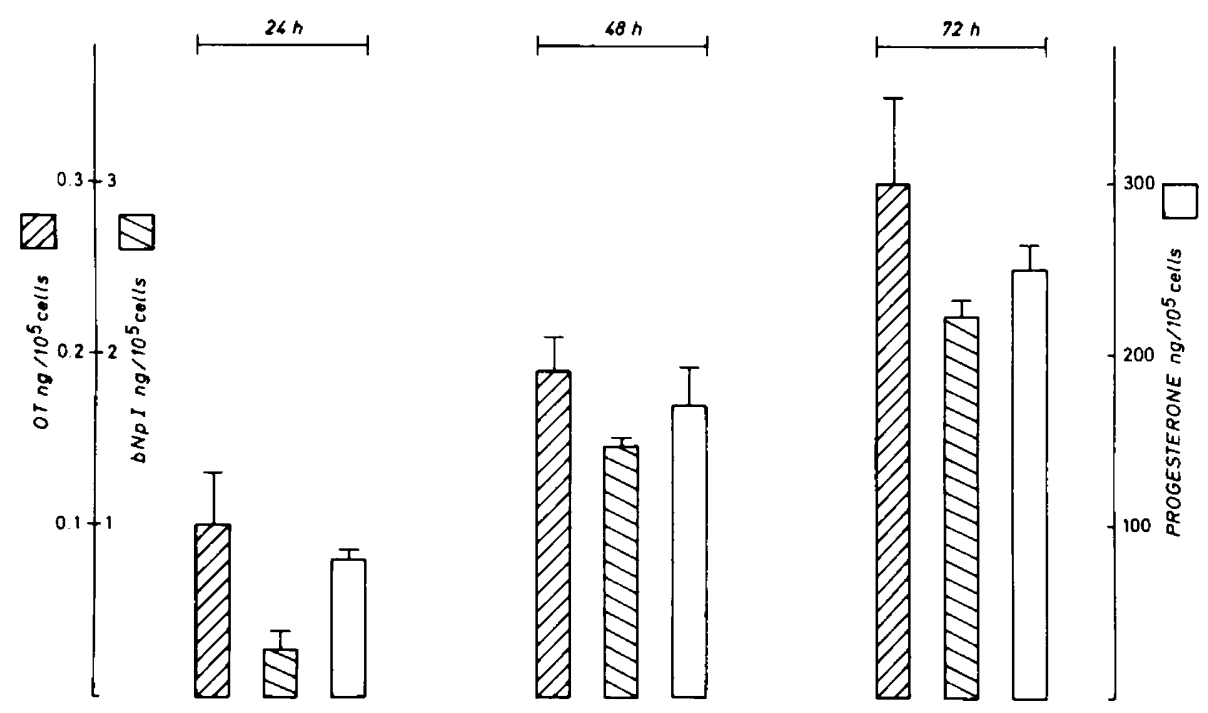

Fig. 4.

Production of OT, $\mathrm{bNpI}$ and progesterone (expressed in $\mathrm{ng} / 10^{5}$ cells, mean $\pm \mathrm{SEM}$ for 4 replicate cultures) by bovine granulosa cells in function of the indicated incubation time.

nature of $O T$ produced by cultured granulosa cells, gel filtration chromatography reveals similar elution profiles of ovarian OT and synthetic OT, while HPLC analyses evidence some heterogeneity of the granulosa cell product, $65 \%$ of the OTimmunoreactivity reflecting the authentic hormone. As the other peak of OT-immunoreactivity derives from the material contained in fractions 13-18 from G-25 chromatography, the molecular weight must be close to the OT one and, thus, this peak does not represent some larger precursor. This unknown peptide is not one of the other neurohypophysial peptides, AVP or AVT, as indicated by HPLC studies, and we hypothesize that it may represent either a degradation product of OT or a small intermediary form of the OT synthetic pathway. In each case, the presence of this OT-like immunoreactive material can partially explain a molar ration OT:bNp I slightly higher than the theoretical one $(1: 1)$.

We think that the observed findings reflect an active biosynthesis of the OT-related peptides by ovarian cells rather than a passive release of these hormones, and different experimental facts argue for an active synthetic process analogous to the hypothalamo-neurohypophysial pathway by cleavage from a common precursor (Land et al. 1983): first, the parallel and correlated productions of OT and bNp I with a molar ratio rather close to the theoretical one and, mainly, the gradual culture medium enrichment in OT and bNp I along the incubation time, with a total amount of OT and bNp I produced 4-5 times greater than the initial cellular content of these peptides. Otherwise, direct evidence for OT synthesis by corpus luteum has been provided by two other groups (Ivell \& Richter 1984; Swann et al. 1984) but there have been no previous reports referring to granulosa cells.

Another aspect of our findings deserves some discussion. In a preliminary report (Geenen et al. 1984), we showed a significant negative correlation between the productions of neurophysins and progesterone by cultured granulosa cells from large follicles, and a negative but not significant correlation between the productions of OT and progesterone. This discrepancy with the present results could be due to the fact that we in the previous experiment have used a radioimmunoassay detecting all the immunoreactive forms of neurophysins, including vasopressin-neurophysin, and that we have considered only one period of incubation and not successive incubation times as in this work. In the light of the present data, it appears that the release and, probably, the biosynthesis of OT and bNp I by cultured bovine granulosa cells are closely related to the progesterone production and, there- 
fore, to the luteinization of these cells. Other authors have reported that OT could influence the steroidogenesis of bovine corpus luteum; small doses of OT $(4-40 \mathrm{mIU} / \mathrm{mI}$, corresponding to $8-80 \mathrm{ng} / \mathrm{ml}$ as $1 \mu \mathrm{IU}= \pm 2 \mathrm{pg}$ OT), stimulated the production of progesterone while higher OT concentrations $(800 \mathrm{mIU} / \mathrm{ml})$ inhibited the basal progesterone production and the response of luteal cells to hCG (Tan et al. 1982a). In ewes and cows, circulating OT levels increase in parallel with the progesterone concentrations, and the highest values are found in the early and midluteal phases (Schams et al. 1982; Schams 1983). The present study is in accordance with these reports and we think that the cultures of granulosa cells constitute a suitable approach to investigate more profoundly the ovarian function of OT and the paracrine relationship between OT and the gonadal steroidogenesis, especially during the early phases of luteinization. Recently, it was reported that the neurohypophysial peptides AVT, AVP and OT exerted a direct stimulatory effect on the biosynthesis of pregnenolone and progesterone by cultured rat testicular cells (Adashi et al. 1984). A similar mechanism could occur in the ovary and could be postulated on the basis of the positive correlation observed in this study between the production of OT and progesterone by cultured luteinizing granulosa cells.

\section{Acknowledgments}

We wish to thank Mrs. Y. Heinemann and V. Lechanteur who typed the manuscript and Mr. J. Collette who drew all graphs.

Dr. V. Geenen is Aspirant du Fonds National de la Recherche Scientifique de Belgique.

\section{References}

Adashi E Y, Tucker E M \& Hsueh A J W (1984): Direct regulation of rat testicular steroidogenesis by neurohypophysial hormones. J Biol Chem 259: 5440-5446.

Fields P A, Elridge R K, Fuchs A-R, Roberts R F \& Fields M J (1983): Human placental and bovine corpora luteal oxytocin. Endocrinology 112: 1544-1546.

Flint A P F \& Sheldrick E L (1982): Ovarian secretion of oxytocin is stimulated by prostaglandin. Nature 297: $587-588$.
Geenen V, Legros J J, Hazée-Hagelstein M T, LouisKohn F, Lecomte-Yerna M J \& Franchimont P (1984): Oxytocin and neurophysin in cultures of bovine luteinizing granulosa cells and inverse relationship with progesterone synthesis. J Steroid Biochem 20: 1508, abstr F 19.

Greenwood F C, Hunter W M \& Glover J S (1963): The preparation of [ $\left.{ }^{131} \mathrm{I}\right]$ labelled human growth hormone of high specific radioactivity. Biochem J 89: 114-123.

Henderson K M \& Moon Y S (1979): Luteinization of bovine granulosa cells and corpus luteum formation associated with loss of androgen-aromatizing ability. J Reprod Fertil 56: 89-97.

Henderson K M \& Franchimont P (1981): Regulation of inhibin production by bovine ovarian cells in vitro. $\mathrm{J}$ Reprod Fertil 63: 431-442.

Ivell R \& Richter D (1984): The gene for the hypothalamic peptide hormone oxytocin is highly expressed in the bovine corpus luteum: biosynthesis, structure and sequence analysis. EMBO J 3: 2351-2354.

Khan-Dawood F S \& Dawood M Y (1983): Human ovaries contain immunoreactive oxytocin. J Clin Endocrinol Metab 57: 1129-1132.

Land H, Grez M, Ruppert S, Schmale H, Rehbein M, Richter D \& Schütz G (1983): Deduced amino acid sequence from the bovine oxytocin-neurophysin I precursor cDNA. Nature 302: 342-344.

Legros J J (1976): Les neurophysines. Recherches méthodologiques, expérimentales et cliniques. Masson, Paris.

Legros J J \& Franchimont P (1971): The purification and modification of immunological and physicochemical behaviour of iodinated posterior pituitary hormones. In: Kirkham K E \& Hunter W M (eds). Radioimmunoassay Methods, 40-41. Churchill Livingstone, Edinburgh.

Roberts J S, Mc Cracken J A, Gavagan J E \& Soloff M S (1976): Oxytocin-stimulated release of prostaglandin F2 $\alpha$ from ovine endometrium in vivo: correlations with estrous-cycle and oxytocin-receptor binding. Endocrinology 99: 1107-1114.

Robinson I C A F (1980): The development and evaluation of a sensitive and specific radioimmunoassay for oxytocin in unextracted plasma. J Immunoassay 1 : $323-347$.

Schams D (1983): Oxytocin determination by radioimmunoassay. III. Improvement to subpicogram sensitivity and application to blood levels in cyclic cattle. Acta Endocrinol (Copenh) 103: 180-183.

Schams D, Lahlou-Kassi A \& Glatzel P (1982): Oxytocin concentration in peripherical blood during the oestrous cycle and after ovariectomy in two breeds of sheep with high and low fecundity. J Endocrinol 92: $9-13$.

Schams D, Prokopp S \& Barth D (1983): The effect of active and passive immunization against oxytocin and ovarian cyclicity in ewes. Acta Endocrinol (Copenh) 103: $337-344$. 
Swann R W, O'Shaughnessy P J, Birkett S D, Wathes D C, Porter D G \& Pickering B $\Upsilon$ (1984): Biosynthesis of oxytocin in the corpus luteum. FEBS Lett 174: 262265.

Tan G J S, Tweedale R \& Biggs J S G (1982a): Effects of oxytocin on the bovine corpus luteum of early pregnancy. J Reprod Fertil 66: 75-78.

Tan G J S, Tweedale R \& Biggs J S G (1982b): Oxytocin may play a role in the control of the human corpus luteum. J Endocrinol 95: 65-70.

Wathes D C \& Swann R W (1982): Is oxytocin an ovarian hormone? Nature 297: 225-227.

Wathes D C, Swann R W, Pickering B T, Porter D G, Hull M G R \& Drife J O (1982): Neurohypophysial hormones in human ovary. Lancet 2: 410-412.
Wathes D C, Swann R W, Birkett S D, Porter D G \& Pickering B T (1983): Characterization of oxytocin, vasopressin and neurophysin from the bovine corpus luteum. Endocrinology 113: 693-698.

Wathes D C, Swann R W \& Pickering B T (1984): Variations in oxytocin, vasopressin and neurophysin concentrations in the bovine ovary during the oestrous cycle and pregnancy. J Reprod Fertil 71: 551-557.

Received on January 28th, 1985. 